\title{
The Impact of Tax Apportionment on Fiscal Equalization: A Case Study of Turkish Metropolitan Municipalities
}

\author{
Prof. Dr. Naci Tolga Saruç (İstanbul University, Turkey) \\ Prof. Dr. İsa Sağbaş (Afyon Kocatepe University, Turkey) \\ Dr. Recep Yorulmaz (Afyon Kocatepe University, Turkey)
}

\begin{abstract}
As a monthly basis, $6 \%$ of tax revenues collected within provincial borders is allocated by central government as fiscal transfers to 30 metropolitan municipalities of Turkey. These transfers are the most important external revenue of the metropolitan municipalities. The fact that metropolitan cities have a different level of wealth causes the difference between the amounts of taxes collected in the provinces. The lack of tax apportionment policy further increases the disparity of fiscal transfers, since a significant part of major taxes are collected in a few metropolitan cities. In this study, a simulation of tax apportionment is carried out. Taxes and fiscal transfers before and after-tax apportionment are compared. Inequality measures (e.g. Gini coefficient) show that fiscal equalization is promoted after tax apportionment.
\end{abstract}

\section{Introduction}

In Turkey, the most important revenue source of the municipalities is intergovernmental transfers. Fiscal transfers are allocated to reduce both vertical and horizontal fiscal inequities. The ultimate goal is that local governments could efficiently provide the services with sufficient financial resources. Strong local governments are needed to realize the benefits from decentralization. In order to have strong local governments, there should be a well-designed intergovernmental transfer system that promotes economic efficiency and equity.

In Turkey, $77 \%$ of the total population lives in metropolitan cities. Metropolitan areas contribute significantly to the economy of the country with their human capital. Due to their specific features (such as high density population and rapid industrialization), the intergovernmental transfer system for metropolitan municipalities differ from standard municipalities. Metropolitan municipalities receive $6 \%$ of the tax revenues collected within provincial boundaries that is called as derivation principle.

Tax-indexed intergovernmental transfers are the most important external revenue of metropolitan municipalities. Due to the fact that the metropolitan cities have different levels of wealth, different amount of taxes is collected. This causes horizontal inequity between metropolitan areas.

Since Turkey is a unitary state, taxes are collected where it is paid regardless where it is accrued. The lack of tax apportionment policy further increases the disparity of fiscal transfers between metropolitan areas, since a significant part of major taxes are collected in a few metropolitan cities. In this study, a simulation of tax apportionment will be conducted. Taxes and fiscal transfers before and after-tax apportionment are compared to examine the impact of tax apportionment on fiscal equalization.

The following section provides theoretical background for fiscal equalization and tax apportionment. In the empirical part of the study, taxes and fiscal transfers before and after-tax apportionment are compared based on a simulation study. The study concludes with general remarks.

\section{Theory of Fiscal Equalization and Tax Apportionment}

In all but a few countries unitary or federal, central governments transfer money to lower level governments (states, provinces, municipalities). These are called as intergovernmental transfers, which means 'a transfer of resources between politically separate units of government rather than transfers within the same administrative unit' (Heald, 1983). Intergovernmental transfers are distributed for a number of objectives. The equity objectives of transfers are explained as follows.

\section{a) To correct vertical fiscal imbalance}

The central government may seek a more efficient allocation of resources through a transfer policy. The advantages of decentralization mostly arise from decentralization of expenditures, in terms of the decisions regarding both the mixture of local public goods and services and their actual production. Decentralization of expenditures has some shortcomings e.g. in some cases, inconsistencies with national interests, planning and coordination; increasing corruption; extravagant and irresponsible spending. With an effective central control mechanism, these disadvantages may be eliminated or controlled.

Decentralization of revenue collection has less potential advantages than decentralization of expenditure. It is generally less efficient with the exception of a few sources such as property taxation. Hewitt (1991) has determined two main reasons for the lower efficiency of decentralized tax collection: 
i) administrative inefficiency: Decentralized tax collection is often more costly to administer for informational reasons. A centralized system requires only one file on each economic entity, and is therefore less costly. Some companies operate in more than one area. In this situation, it is more difficult to assess taxable income with decentralized tax collection and this causes 'piggybacking' with detrimental impact on economic efficiency additionally.

ii) economic inefficiency: A high tax in one jurisdiction can lead to relocation of economic activity to another jurisdiction. This may create undesirable incentives for relocation of economic activities.

This contradiction between the advantages of expenditure decentralization and the disadvantages of decentralized revenue (tax) collection causes a tension between efficient service delivery and revenue collection. As a result, local government resources fall short of their responsibilities. This fiscal deficit, which is termed vertical fiscal imbalance, has to be offset by intergovernmental transfers which serve to resolve this contradiction and allow a country to rely on normally more efficient centralized tax collection while still availing itself of decentralized expenditure decisions (Hewitt, 1991).

\section{b) To correct horizontal fiscal imbalance}

A number of horizontal variations between local areas may cause disparities in both their fiscal capacity and expenditure needs. Intergovernmental transfers could be used to correct these disparities and this correction is termed as fiscal equalization. Since fiscal equalization is the main theme of this thesis, its theory will be explained in greater detail in the following section.

It should be pointed out that the objectives of intergovernmental transfers should not be evaluated separately since they are not mutually exclusive in practice. Political intervention should also be included in this evaluation, because it may affect the consequences of the impact of transfers on efficiency and equity significantly. For example, evidence confirms in the U.S. case that political factors explain the grant system better than the objectives of intergovernmental transfers. Inman (1988) found little evidence that intergovernmental transfers are used to internalize externalities.

Horizontal fiscal equalization aims at reducing disparities in the fiscal condition (fiscal gap) of local governments. Vertical fiscal equalization aims at reducing the budgetary gap of local authorities. The fiscal condition (fiscal gap) of a local government is defined as the gap between its expenditure needs and its revenueraising capacity, whereas budgetary gap is determined by actual expenditures and revenues (Ladd, 1994).

A policy that corrects horizontal fiscal imbalance employs the following formula in the allocation:

$$
\mathrm{T}_{\mathrm{i}}=\mathrm{EN}_{\mathrm{i}}-\mathrm{FC}_{\mathrm{i}}
$$

where:

$\mathrm{T}_{\mathrm{i}} \quad$ transfer to local authority $\square$

$\mathrm{EN}_{\mathrm{i}} \quad$ expenditure need of local authority $\square$

$\mathrm{FC}_{\mathrm{i}} \quad$ fiscal capacity of local authority $\square$

A policy that corrects vertical fiscal imbalance employs the following formula in the allocation. This produces a deficiency grant system:

$$
\mathrm{T} \square=\mathrm{AE} \square-\mathrm{AR} \square
$$

where:

$\mathrm{T}_{\mathrm{i}} \quad$ transfer to local authority $\square$

AE $\square \quad$ actual expenditures of local authority $\square$

AR $\square \quad$ actual revenues of local authority $\square$

Compensation for variations in fiscal condition can be advocated on equity and efficiency grounds, but compensation for a budgetary gap could bring efficiency losses. The main reason for the efficiency losses is that vertical fiscal equalization corrects a budgetary gap which is an outcome of budgetary performance.

Ahmad and Craig (1997) also point out that if grants were designed solely to close the vertical imbalance, there would be little incentive for local governments to make local revenue effort or restrict or manage expenditures efficiently. Consequently, this system is likely to lead to macroeconomic difficulties as well as indeterminate bargaining between the central and local governments.

Keating and Midwinter (1994) briefly define fiscal equalization: 'it is the redistribution of resources among jurisdictions with the aim of reducing disparities'. It is defined in the United States as the process through which a central government makes funds available to lower level governments with the objective of reducing the degree of inequality in the revenues that such governments can raise using their own revenue instruments (Pearce, 1992).

In Australia, it is defined as the distribution of revenue grants, which give each state the capacity to provide the average standard of state-type public services assuming that it does so at an average level of operational efficiency and makes the average effort to raise revenue from its own sources (Commonwealth Grants Commission, 1995). In the UK, it is defined as allocating grants with the aim of equalizing the differences in assessed costs between 
areas, leaving council tax payers everywhere able to pay broadly the same council tax for their valuation band and receive the same standard of service (SSA Handbook, 1994).

The common point in these definitions is to correct horizontal fiscal disparities which arise from two sources: those arising from the differential costs of providing local public goods - needs disparities-, and those due to differential access to resources -resource disparities - (Oakland, 1994). Needs disparities arise from the varying costs of providing a given range of services in different localities because of physical, demographic, or economic factors; resource disparities stem from the differing wealth, income, or tax bases of jurisdictions, which allow some to raise more revenue for a given tax rate than others (Keating and Midwinter, 1994).

The theory of fiscal equalization has a rationale based on notions of the potential equity and efficiency gains. Jackson (1991) points out the essence of these gains: horizontal equity requires that identical individuals living in different local authorities should equally be well off (equity) and should not be disadvantaged because of location (efficiency). Keating and Midwinter (1994) call equity gains social justifications, and efficiency gains as economic justifications for fiscal equalization.

It is widely acknowledged that a well-functioning intergovernmental fiscal system will be conducive to resource mobilization, macroeconomic stabilization, overall performance of the economy, and fiscal equity. A wellfunctioning intergovernmental fiscal system requires a well-functioning intergovernmental transfer system to promote fiscal equity. Allocating transfers according to fiscal equalization principles is indispensable for designing a well-functioning intergovernmental transfer system. The topic, fiscal equalization, is, therefore, of considerable concern for designing a 'good' intergovernmental fiscal system.

A good intergovernmental fiscal system would not work in the lack of tax apportionment policy where local governments receive transfers from a pool of central taxes. It would be useful to explain the theory of tax apportionment.

Federal states collect corporate and sales taxes in the United States. The differences between the places, where the tax is collected and assessed for the multinational companies might cause problems between states in the federal state countries. Paying the tax at the state of origin for a multinational company might be seen as a problem for other states. As a solution to this problem 'formulary tax apportionment' system has been used since 19th century (Weiner, 2005).

Formulary tax apportionment means redistribution of the net profit of a multinational firm among its operating states using a specific formula (Gordon and Wilson, 1986). This system is used as an alternative of separate accounting (SA) system, which requires separate accounting for the parent company and its subsidiaries (Gupta and Hofmann, 2003). It is important to apply the arm's length principal, under the separate entity accounting, to prevent any potential tax disadvantages. Further, arm's length principal might eliminate the disadvantages of price transactions amongst the entities of the parent company.

According to the separate accounting principle, the multinational company recognizes each affiliated entity as a separate asset. The multinational company calculates the income of each affiliated enterprise to their own accounting records and pays the tax rate for that region of those affiliated enterprises. In the meantime, the headquarters of the multinational corporation, as an independent unit from its affiliated institutions, keeps its accounting records in compliance with the arm's length and pays its tax. The arm's length principle requires separate accounting application. In addition, the arm's length principle requires the price applied for the purchase or sale of goods or services between the parent company and its subsidiaries to be made at the price to be incurred if such a relationship does not exist. For this reason, the firm should use the arm's length prices in the market, when purchasing amongst its units. The purpose of separate accounting and arm's length principles is approximating the taxation of the affiliated enterprises and the taxation of the independent units (Hellerstein, 1993; Edmiston, 2002).

The most important advantage of the formulary tax apportionment principal is preventing the separate accounting amongst the entities of the parent company, so there will be no need for the arm's length principal at all (Anand and Sansing, 2000; Nielsen, et. all., 2001). The formulary tax apportionment principal has been used in the U.S and Canada for decades. The main purpose of this principle is to ensure the multinational enterprises pay their corporate taxes not only in the state of origin but also in states of destinations where their consumption occurs and income earned. It is because, the taxpayer multinational firms also benefit from common public goods and services in all the states in which they operate. They also make the relevant state responsible for the cost of their production/consumption.

The European Commission decided to apply a new strategy on the corporate tax system within the European area in 2001. This new strategy comprises of redistribution of the corporate tax, which was paid by EU based enterprises, within the member countries. However, there is no such formula in practice to redistribute the corporate income tax within the member countries in the EU (Weiner, 2002a, 2002b, 2005).

There are some problems of the formulary tax apportionment principle in practice, because of state specific differences in the U.S and Canada (Weiner, 2001). For instance, the states might choose to apply different policies on the weights and specifications of the apportionment formulae. Moreover, there might be some other differences 
between states, such as tax rates and exemptions. These differences have detrimental effects on the expected utility benefit of these formulae (Weiner, 1999).

\section{Empirical Study}

There are 30 metropolitan municipalities in Turkey. As it is presented in the Table 1 below, $77 \%$ of the total population lives in the metropolitan cities. Doing so, $78 \%$ percent of the gross domestic product (GDP) is produced by those cities. In line with these facts, the $72 \%$ of the total tax is collected in those cities. In practice, all the cities of Turkey contribute to the total GDP. However, the results presented in Table 1, suggest that $72 \%$ of the total production and consumption in the country are occurred in 30 big cities, while the remaining $28 \%$ is made in 51 cities. This is a bias outcome for the majority of the country.

\begin{tabular}{|l|c|c|c|}
\hline & $\begin{array}{c}\text { Population } \\
\text { (million) }\end{array}$ & $\begin{array}{c}\text { GDP } \\
\text { (million TL) }\end{array}$ & $\begin{array}{c}\text { Tax } \\
\text { (million TL) }\end{array}$ \\
\hline Turkey & 79,8 & 2201 & 529 \\
\hline 30 Metropolitan Municipalities & 61,8 & 1725 & 384 \\
\hline MM/Turkey (\%) & 77 & 78 & 72 \\
\hline
\end{tabular}

Table 1: Basic Indicators of the Metropolitan Municipalities

With the establishment of the metropolitan municipalities in 1984, a fiscal transfer system for the metropolitan municipalities was initiated. The history of fiscal transfers from central government to the metropolitan municipalities in Turkey can be examined in three periods:

i) The period of 1984 - 2008: In this period, 5\% of the tax revenues collected within the borders of the metropolitan municipalities was transferred.

ii) The period of $2008-2012$ : In this period, $5 \%$ of the general budget tax revenues collected in the metropolitan municipal borders and $30 \%$ of the shares allocated to the districts of metropolitan municipalities were collected as the municipal share of the metropolitan municipality.

iii) Post - 2012 period: In this period, 6 percent of the general budget tax revenue collections made within the municipal borders of the metropolitan municipality, except for the private consumption tax collected from the goods listed in Private Consumption Tax (petroleum and natural gas products). These shares are calculated monthly by the Ministry of Finance and transferred directly to these municipalities

The rate of consumption is decreasing as income increases. In a study by Zenginobuz et al. (2006) (quoted in Demir, 2013), the share of the consumption tax was investigated by using the shares allocated to consumption as of $20 \%$ income groups. In this study, the tax burden on group consumption with the lowest income level of $20 \%$ corresponds to $22.9 \%$ of the household income; the rate of household income was found to be $16.3 \%$ for the ones with the highest income level of $20 \%$. Moreover, this rate dropped to $12.6 \%$ for the households in the richest $5 \%$. Despite the fact that, there are income-generating activities and consumption in other provinces, the majority of the companies that are obliged to pay these taxes gathered around the metropolitan cities like İstanbul and Ankara, which is the reason why the vast majority of the taxes on income and consumption are collected in the metropolitan municipalities.

The relationship between the share of a province from government expenditure and the tax paid by the province is defined as regional net fiscal incidence. The regional net fiscal incidence is calculated by examining the difference between the share of a province from government expenditure and the tax paid by the province. This rate remains negative for the vast majority of the provinces of Turkey. There is an 'income transfer' from the cities that have positive regional fiscal incidence to those that have negative fiscal incidence. Hence, the formulary tax apportionment principle would bring a new point of view in terms of the regional net fiscal incidence. This new formula might change the negative fiscal incidence into positive for the relevant cities.

The relatively small cities might be called free riders since metropolitan municipalities seem to collect vast majority of taxes in the whole country. They might even be perceived as a burden on the metropolitan municipalities. Thus, the metropolitan municipalities might require more from the share of government expenditure. Doing so, the formulary tax apportionment principle would be used to eliminate those obstacles. This new formula would increase the approximate regional tax allocation of some provinces while decreases some others.

Even though Turkey has a unitary state, how much is it necessary to apply the taxation formula that is used in the federal countries like the USA and Canada? Due to the implementation of budgetary unity and decentralization principles in Turkey, it is not important that the tax assessment and tax levy occur at different places. However, there is a very important exception of the decentralization principle in Turkey. The general collected government tax is transferred into the metropolitan municipalities according to the derivation principle. Since some of the tax of metropolitans are originally occurred in other cities; the derivation principle causes an income transfer from the metropolitans that have a small share of general tax transfers to those with a higher share of general tax transfers. 
Since the new tax share of metropolitans that are found with the formulary tax apportionment principle will differ from the current tax transfers of metropolitans, their fiscal transfers will also be different. Therefore, the formulary tax apportionment principle can be used as an instrument to provide financial compensation between metropolitan municipalities. While financial compensation is being carried out from one side, it is expected that there are loser some cities that lose after tax apportionment.

In the tax apportionment, there are 3 factors in the US (property value of the company, wages paid to employees, financial turnover) and 2 factors in Canada (financial turnover, wages paid to employees). The formulary tax apportionment is applied to the corporate income taxes that are collected by the states. The VAT or excise duties that are specific for Turkey are not available in the US, while sales tax is collected by the states. Therefore, there is no need for the tax apportionment for sale taxes since consumption taxes are collected where the tax occurs.

Before presenting the tax apportionment analyses for the metropolitans, we explore some important preliminary statistics. According to these statistics, the metropolitans of Turkey have heterogeneous concept in terms of their GDP levels and tax revenues.

As it is presented in Table 2, 28 out of 30 metropolitans have populations under five million. Moreover, 9 metropolitans have populations under 1 million.

\begin{tabular}{|l|c|c|c|}
\hline Population & Frequency & $\%$ & Cumulative \% \\
\hline Between 0-1 million & 9 & 30 & 30 \\
\hline Between 1-5 million & 19 & 63 & 93 \\
\hline Between 5-10 million & 1 & 3 & 96 \\
\hline Above 10 million & 1 & 3 & 100 \\
\hline
\end{tabular}

Table 2: Distribution of Metropolitan Municipalities by Population Size

In Table 3, we present the GDP levels of metropolitans. Doing so, $23 \%$ of the metropolitans have low income, $45 \%$ have middle incomes, and $29 \%$ of the metropolitans have high income levels in Turkey.

\begin{tabular}{|l|c|c|c|}
\hline Per capita income & Frequency & $\%$ & Cumulative \% \\
\hline Between 0-14 million TL & 7 & 23 & 23 \\
\hline Between 15 -24 million TL & 14 & 45 & 70 \\
\hline Between 25 - 42 million TL & 9 & 29 & 100 \\
\hline
\end{tabular}

Table 3: Distribution of Metropolitan Municipalities by Per Capita Income (GDP)

Appendix 1 presents the differences of tax revenues between metropolitans. Accordingly, the maximum province has 96 times higher tax revenue than the minimum province.

We use three indicators while using the tax apportionment formula for the metropolitans: tax revenue, GDP and the population of the metropolitans. The following table explores the correlations among these three indicators. According to the results, there are positive and strong relationships among the indicators.

\begin{tabular}{|l|c|c|c|}
\hline & Tax & GDP & Population \\
\hline Tax & 1 & - & - \\
\hline GDP & 0,961 & 1 & - \\
\hline Population & 0,978 & 0,991 & 1 \\
\hline
\end{tabular}

Table 4: Correlations of the Indicators

Moreover, the following table presents a simple regression analyses between tax revenue per person and population; and tax revenue per person and GDP per capita indicators respectively. Since there is a strong correlation between population and GDP per capita indicators, we did not run a regression because of the autocorrelation problem. As expected, the results suggest that the GDP for the metropolitan affects the tax revenue per person more than the population.

\begin{tabular}{|l|c|c|}
\hline $\begin{array}{l}\text { Independent } \\
\text { Dependent }\end{array}$ & Tax revenue per person & Tax revenue per person \\
\hline Population & 1,01 & - \\
\hline GDP & $(2,47)^{*}$ & 2,51 \\
& - & $(2,71)^{*}$ \\
\hline $\mathrm{R}^{2}$ & & 0,208 \\
\hline $\mathrm{N}$ & 0,179 & 30 \\
\hline
\end{tabular}

Table 5: Simple Regression Analysis Results Between Tax Revenue, GDP and Population

* Figures in parentheses indicate $t$-stats. Coefficient is significant at $1 \%$ level. 
In this study, we use the following formula to calculate the tax apportionment without distinction of the tax type for the metropolitans. We use the coefficients that are found in the regression analyses to calculate the multiplier in the formula. Doing so, the multiplier of GDP is 0.7 , while it is 0.3 for population. Tax apportionment for the metropolitans $=$
$[(G D P$ for the metropolitans /total GDP for the metropolitans $) \times(0,7 \times$ total tax revenue for the metropolitans $)]$
+
[(population of the metropolitan / total population of the metropolitans $) \times(0,3 \times$ total tax revenue for the
metropolitans $)]$

Using the tables from Appendix 1, we created the following two tables. Three major indicators (max/min ratio, standard deviation and range), calculated before and after the tax apportionment for tax revenues and fiscal transfers, showed a significant reduction after tax apportionment. The difference between the metropolitan which has the highest fiscal transfer per person and the least metropolitan decreased. The decrease in the standard deviation indicates that the concentration around the average value increases in both tax revenues and fiscal transfers. It is observed that there is a significant decrease in the indicator interval, which shows the difference between the largest value and the smallest value after tax apportionment.

\begin{tabular}{|l|c|c|c|c|}
\hline \multirow{2}{*}{} & \multicolumn{2}{|c|}{ Tax revenue } & \multicolumn{2}{c|}{ Fiscal Transfers } \\
\cline { 2 - 5 } & $\begin{array}{c}\text { Before tax } \\
\text { apportionment }\end{array}$ & $\begin{array}{c}\text { After tax } \\
\text { apportionment }\end{array}$ & $\begin{array}{c}\text { Before tax } \\
\text { apportionment }\end{array}$ & $\begin{array}{c}\text { After tax } \\
\text { apportionment }\end{array}$ \\
\hline Max/min ratio & 96 & 2,5 & 105 & 2,5 \\
\hline Standard deviation & 6,21 & 1,27 & 10,3 & 7,6 \\
\hline Range & 31,3 & 5,1 & 52,3 & 30,7 \\
\hline
\end{tabular}

Table 6: Some Inequality Indicators Before and After-Tax Apportionment

\begin{tabular}{|l|l|l|l|}
\hline \multicolumn{2}{|c|}{ Before tax apportionment } & \multicolumn{2}{c|}{ After tax apportionment } \\
\hline \multicolumn{1}{|c|}{ Measure } & Value & \multicolumn{1}{c|}{ Value } \\
\hline Number of Categories & 30 & Number of Categories & 30 \\
\hline Maximum Entropy & 3,40 & Maximum Entropy & 3,40 \\
\hline Entropy & 2,69 & Entropy & 3,37 \\
\hline Normalized Entropy & 0,79 & Normalized Entropy & 0,99 \\
\hline Max. Entropy - Entropy & 0,71 & Max. Entropy - Entropy & 0,02 \\
\hline Theil Entropy Index & 0,71 & Theil Entropy Index & 0,02 \\
\hline Exponential Index & 0,07 & Exponential Index & 0,03 \\
\hline Herfindahl & 0,12 & Herfindahl & 0,03 \\
\hline Normalized Herfindahl & 0,09 & Normalized Herfindahl & 0,001 \\
\hline Rosenbluth & 0,08 & Rosenbluth & 0,03 \\
\hline Gini & 0,59 & Gini & 0,13 \\
\hline Concentration & 0,61 & Concentration & 0,13 \\
\hline Ricci-Schutz (Pietra) & 0,47 & Ricci-Schutz (Pietra) & 0,09 \\
\hline Atkinson & 0,29 & Atkinson & 0,01 \\
\hline Kolm & 2,27 & Kolm & 9,08 \\
\hline Coefficient of Variation & 1,60 & Coefficient of Variation & 0,23 \\
\hline Squared Coefficient of Variation & 2,56 & Squared Coefficient of Variation & 0,05 \\
\hline
\end{tabular}

Table 7: Inequality Indicators for Fiscal Transfers Before and After-Tax Apportionment

The inequality indicators such as Gini, Atkinson etc. prove that the inequalities in the distribution of tax revenues and fiscal transfers are decreased after the tax apportionment. The findings from the above two tables confirm that the disparities in the distribution of tax revenues and fiscal transfers between the metropolitan cities are reduced after tax apportionment. It could be argued that the taxation based on empirical findings diminished the horizontal fiscal imbalance among the metropolitan municipalities and affected the fiscal equilibrium positively.

\section{General Remarks and Conclusion}

There are 30 metropolitan municipalities in Turkey. $77 \%$ of the total population lives in metropolitan cities. While $78 \%$ of the GDP of the country is produced in metropolitans, $72 \%$ of the taxes are collected. $6 \%$ of tax revenues collected within provincial borders is given as fiscal transfers to the metropolitan municipalities. Tax based fiscal transfers are the most significant external revenue of the metropolitan municipalities. The fact that the metropolitan cities have different levels of wealth causes the differences in the amount of tax revenues collected in the provinces. Moreover, the fact that the fiscal transfers are indexed by the taxation causes differentiation in the amount of fiscal transfers per capita received by the metropolitans. The lack of a tax apportionment policy in 
Turkey further increases the disparity of fiscal transfers. In this study, the tax revenue and fiscal transfer simulation of the metropolitan cities were carried out without tax apportionment and after apportionment. The findings show that after tax apportionment, fiscal transfers are more successful than achieving the goal of fiscal balancing.

Since some part of the tax share of metropolitans are originally occurred in other cities; the derivation principle causes an income transfer from the metropolitans which have small shares of general tax transfers to those with higher shares of general tax transfers.

Since the new tax share of metropolitans that are found with the formulary tax apportionment principle will differ from the current tax transfers of metropolitans, their fiscal transfers will also be different. Therefore, the formulary tax apportionment principle can be used as an instrument to provide financial compensation between metropolitan municipalities. While financial compensation is being carried out from one side, it is expected that there will be loser cities after tax apportionment.

Three major indicators ( $\mathrm{max} / \mathrm{min}$ ratio, standard deviation and range), calculated before and after the tax apportionment for tax revenues and fiscal transfers, showed a significant reduction after tax apportionment. The difference between the metropolitan in which has the highest fiscal transfer per person and the least metropolitan decreased. The decrease in the standard deviation indicates that the concentration around the average value increases in both tax revenues and fiscal transfers. It is observed that there is a significant decrease in the indicator interval, which shows the difference between the largest value and the smallest value after tax apportionment.

The inequality indicators such as Gini, Atkinson etc. prove that the inequalities in the distribution of tax revenues and fiscal transfers are decreased after the tax apportionment using formulary tax apportionment formula. Findings from the above two tables confirm that the disparities in the distribution of tax revenues and fiscal transfers between the metropolitan cities are reduced after tax apportionment. It can be argued that the taxation based on empirical findings diminished the horizontal fiscal imbalance among the metropolitan municipalities and affected the fiscal equilibrium positively.

\section{References}

- Ahmad, E. and Craig, J. (1997) Intergovernmental Transfers, in Ter-Minassian, T. (ed.) Fiscal Federalism in Theory and Practice, IMF, Washington, D.C.

- Anand, B. and Sansing, R. (2000) The Weighting Game: Formula Apportionment as an Instrument of Public Policy, 53 National Tax Journal 2, pp.18.

- Commonwealth Grants Commission (1995) Report on General Revenue Grant Relativities, 1995 Update, Australian Government Publishing Service, Canberra.

- Demir, I.C. (2013) Tax Burden in Turkey, Dora, Bursa (published in Turkish).

- Edmiston, K. (2002) Strategic Apportionment of the State Corporate Income Tax, 55 National Tax Journal 2, pp.239-62.

- Gordon, R. and Wilson, J. (1986) An Examination of Multi-Jurisdictional Corporate Income Taxation Under Formula apportionment", 54 Econometrica 6, pp. 1357-73.

- Gupta, S. and Hofmann, M.A. (2003) The Effect of State Income Tax Apportionment and Tax Incentives on New Capital Expenditures, Journal of the American Taxation Association (Supplement 2003).

- Heald, D. (1983) Public Expenditure, Martin Robertson \& Company Ltd., Oxford

- Hellerstein, J. (1993) Federal Income Taxation of Multinationals: Replacement of Separate Accounting with Formulary Apportionment, 60 Tax Notes 10, pp. 1131-45.

- Hewitt, D.P. (1991) Transfers to Local Governments, in Chu, K. and Hemming, R. (eds.) Public Expenditure Handbook: A Guide to Public Expenditure Policy Issues in Developing Countries, IMF, Washington, D.C.

- Hewitt, D.P. (1991) Transfers to Local Governments, in Chu, K. and Hemming, R. (eds.) Public Expenditure Handbook: A Guide to Public Expenditure Policy Issues in Developing Countries, IMF, Washington, D.C.

- Inman, R.P. (1988) Federal Assistance and Local Services in the United States: The Evolution of a New Federalist Fiscal Order, in Rosen, H.S. (ed.) Fiscal Federalism: Quantitative Studies, Chicago University Press, Chicago

- Jackson, P.M. (1991) Review of Bramley (1990) Environment and Planning C: Government and Policy, v.9.

- Keating, M. and Midwinter, A. (1994) The Politics of Central-Local Grants in Britain and France, Environment and Planning C: Government and Policy, v.12, pp.177-194

- Keating, M. and Midwinter, A. (1994) The Politics of Central-Local Grants in Britain and France, Environment and Planning C: Government and Policy, v.12, pp.177-194 
- $\quad$ Ladd, H.F. (1994) Measuring Disparities in the Fiscal Conditions of Local Governments, in Anderson, J.E. (ed.) Fiscal Equalization for State and Local Government Finance, Praeger in co-operation with the National Tax Association, Westport

- $\quad$ Nielsen, S.B., Pascalis, R.M. and Guttorm, S. (2001), “Tax Spillovers under Separate Accounting and Formula Apportionment", Economic Policy Research Union paper 01-07, Copenhagen Business School.

- Oakland, W.H. (1994) Recognizing and Correcting for Fiscal Disparities: A Critical Analysis, in Anderson, J.E. (ed.) Fiscal Equalization for State and Local Government Finance, Praeger in co-operation with the National Tax Association, Westport

- Pearce, D. (1992) The MIT Dictionary of Modern Economics, MIT Press, Cambridge

- SSA Handbook (1994) SSA Handbook, Department of Environment, 1994/95, London

- Weiner, J.M. (1999) Using the Experience in the U.S. States to Evaluate Issues in Implementing Formula Apportionment at the International Level, OTA Paper 83, Office of Tax Analysis, Washington, D.C.: U.S. Department of the Treasury.

- Weiner, J.M. (2001) The European Union and Formula Apportionment: Caveat Emptor", 41 European Taxation 10 (October), pp. 380-88.

- Weiner, J.M. (2002a) Formulary Apportionment: Possible Solution to the Tax Harmonization Dilemma in the European Union?" Proceedings of the National Tax Association 95th Annual Conference on Taxation, pp. 241-45.

- Weiner, J.M. (2002b) Formulary Apportionment and the Future of Company Taxation in The European Union", 3 CESifo Forum No. 1 (Spring), pp. 10-20.

- Weiner, J.M. (2005), Formulary Apportionment and Group Taxation in the European Union: Insights from the United States and Canada, Taxation Papers.

- Zenginobuz, U, G. Ozerten, I. Saglam, and F. Goksen (2006), From Citizens’ Pocket to State Treasury: Who Pays Tax and How Much? Open Society Institute and Bogazici University, Istanbul (published in Turkish). 